\title{
HIGH PREVALENCE OF UNTREATED AND UNDERTREATED VITAMIN D DEFICIENCY AND INSUFFICIENCY IN PATIENTS WITH INFLAMMATORY BOWEL DISEASE
}

\author{
Viktor Domislović ${ }^{1}$, Darija Vranešić Bender ${ }^{2,3}$, Ana Barišićc ${ }^{2}$, Marko Brinar ${ }^{1,4}$, \\ Dina Ljubas Kelečić ${ }^{2}$, Cecilija Rotim ${ }^{5}$, Martin Novosel $^{4}$, Marija Matašin $^{4}$ and Željko Krznarići,2,4 \\ ${ }^{1}$ Division of Gastroenterology and Hepatology, Department of Internal Medicine, \\ Zagreb University Hospital Centre, Zagreb, Croatia; \\ ${ }^{2}$ Unit of Clinical Nutrition, Zagreb University Hospital Centre, Zagreb, Croatia; \\ ${ }^{3}$ Faculty of Food Technology and Biotechnology, University of Zagreb, Zagreb, Croatia; \\ ${ }^{4}$ School of Medicine, University of Zagreb, Zagreb, Croatia; \\ ${ }^{5}$ Andrija Štampar Teaching Institute of Public Health, Zagreb, Croatia
}

\begin{abstract}
SUMMARY - Inflammatory bowel disease (IBD) patients with vitamin D deficiency show an increased risk of hospital admission, surgery, and loss of response to biologic therapy while high vitamin D levels are identified as a protective factor. Our goal was to investigate the prevalence of untreated and undertreated vitamin $\mathrm{D}$ deficiency and factors associated with vitamin $\mathrm{D}$ deficiency. In this cross-sectional study, we measured serum vitamin $\mathrm{D}$ in a random sample of Caucasian IBD patients. Vitamin D deficiency was defined as $<50 \mathrm{nmol} / \mathrm{L}$ and insufficiency as $50-75 \mathrm{nmol} / \mathrm{L}$. Supplementation was defined as taking 800-2000 IU vitamin D daily. Untreated patients were defined as not taking supplementation and undertreated group as receiving supplementation but showing vitamin $\mathrm{D}$ deficiency or insufficiency despite treatment. Our study included 185 IBD patients, i.e. 126 (68.1\%) with Crohn's disease (CD) and 59 (31.9\%) with ulcerative colitis (UC). Overall, 108 (58.4\%) patients had vitamin D deficiency and 60 (32.4\%) patients vitamin D insufficiency. There were 16 (14.8\%) and $11(18.3 \%)$ treated patients in vitamin D deficiency and vitamin D insufficiency group, respectively. The rate of untreated patients was $81.7 \%(n=49)$ in vitamin D deficiency group and $85.2 \%(n=92)$ in vitamin $\mathrm{D}$ insufficiency group. Tumor necrosis factor alpha inhibitors were associated with higher serum vitamin D levels in CD and UC, and ileal involvement, ileal and ileocolonic resection with lower levels. In conclusion, not only is vitamin D deficiency common in IBD patients but the proportion of untreated and undertreated patients is considerably high. We suggest regular monitoring of vitamin $\mathrm{D}$ levels in IBD patients regardless of receiving vitamin D supplementation therapy.
\end{abstract}

Key words: Inflammatory bowel diseases; Vitamin D deficiency; Crohn's disease; Colitis, ulcerative

\section{Introduction}

Inflammatory bowel disease (IBD) is a relapsingremitting, immune-mediated chronic intestinal condition, which most commonly includes Crohn's disease (CD) and ulcerative colitis (UC) ${ }^{1}$. The incidence and prevalence of IBD that is increasing worldwide points to the importance of investigating protective and risk
Correspondence to: Viktor Domislovic, MD, Division of Gastroenterology and Hepatology, Department of Internal Medicine, Zagreb University Hospital Centre, Kišpatićeva 12, HR-10000 Zagreb, Croatia

E-mail: viktor.domislovic@gmail.com

Received January 17, 2020, accepted February 20, 2020 
factors ${ }^{2,3}$. Epidemiological studies have so far identified a large number of environmental and genetic factors that can affect the risk of IBD, including vitamin $\mathrm{D}$ deficiency, lifestyle (smoking, urban living), medications (antibiotics, oral contraceptive therapy), surgical procedures (appendectomy, tonsillectomy), etc. ${ }^{4}$. In addition, high vitamin $\mathrm{D}$ levels are identified as a protective factor for $\mathrm{CD}$, and possibly $\mathrm{UC}^{4,5}$. Vitamin $\mathrm{D}$ is a pleiotropic hormone lately recognized beyond its role in homeostasis of bone tissue and calcium. Vitamin $\mathrm{D}$ can regulate immune system by affecting $\mathrm{T}$ lymphocytes, dendritic cells and macrophages, but also has a role of protecting and repairing intestinal mucosal barrier ${ }^{6-8}$. CD and UC can lead to vitamin D deficiency due to a variety of reasons such as inflammatory activity, bowel resections, insufficient dietary intake, malabsorption, etc. ${ }^{9,10}$. There is evidence that indicates the existence of a north to south gradient, with the increasing incidence or prevalence of IBD patients in northern countries with less sun exposure and less naturally produced vitamin $\mathrm{D}$ as opposed to southern ones $^{11-13}$. In addition, there is evidence that supports the increased risk of hospital admission, need for surgical intervention and inadequate response to biologic therapy ${ }^{9,14,15}$. These findings indicate the necessity of regular monitoring and appropriate vitamin D supplementation. Novel evidence, however, points to the importance of the protective role of vitamin $\mathrm{D}$ in intestinal epithelium, immunity and microbiota ${ }^{16}$.

The main objective of this study was to determine the prevalence of untreated and undertreated IBD patients among those with vitamin $\mathrm{D}$ deficiency and insufficiency. Additionally, we identified factors associated with vitamin $\mathrm{D}$ deficiency.

\section{Materials and Methods}

\section{Patient data}

This was a cross-sectional study conducted at the Division of Gastroenterology and Hepatology, Department of Internal Medicine, Zagreb University Hospital Centre. We recruited a random sample of Caucasian patients with IBD and measured serum vitamin D levels. Measurements were done equally throughout the four seasons 2018-2019. Inclusion criteria were adult patients diagnosed with IBD, whereas exclusion criteria were systemic infection, bacterial, viral or parasitic infection, diverticulitis, enterocolitis, ischemic colitis, dys- function of the liver (cirrhosis, active hepatitis), primary sclerosing cholangitis, primary biliary cholangitis, chronic kidney disease, rheumatologic diseases (ankylosing spondylitis, arthritis), malignant diseases, autoimmune diseases, hematologic diseases, pregnancy, or refusal to participate. The study was approved by the ethics review board of the Zagreb University Hospital Centre. Each patient signed a written informed consent. The study protocol was in line with ethical guidelines of the 1975 Declaration of Helsinki.

\section{Anthropometric and demographic data}

Data on anthropometric and demographic characteristics, disease history and therapy were obtained from electronic medical records and questionnaires. Body height was measured in standing position without shoes, and body mass without heavy clothing using Omron BF-511. Body mass index (BMI) was calculated as the ratio of weight in kilograms by square of height in meters $\left(\mathrm{kg} / \mathrm{m}^{2}\right)$.

\section{Measurement of disease activity, localization and behavior}

Inflammatory activity was defined using HarveyBradshaw index (HBI) for CD and partial Mayo Score (PMS) for $\mathrm{UC}^{17,18}$. Patients were divided into groups depending on the HBI and PMS scores as follows: $\mathrm{HBI}<5$ remission; $\mathrm{HBI} \geq 5$ active inflammation; PMS $<2$ remission; and PMS $\geq 2$ active inflammation. Disease behavior and localization in CD and disease extent in UC patients were defined according to the Montreal classification and were obtained from electronic medical records ${ }^{19}$.

\section{Disease specific medication}

Disease specific medications that were currently used were included in the analysis. Medication use was defined as taking immunomodulators (azathioprine, methotrexate), tumor necrosis factor alpha (TNF-a) inhibitors (infliximab, adalimumab, golimumab), other biologic agents (vedolizumab, ustekinumab) and corticosteroids. Total biologic therapy was defined as taking TNF-a inhibitors, vedolizumab or ustekinumab.

\section{Vitamin D measurements}

Blood samples for vitamin D analysis were obtained fasting in the morning on the day of entering 
Table 1. Anthropometric and demographic data of the study population

\begin{tabular}{|c|c|c|c|}
\hline Variable & \begin{tabular}{|l} 
Total \\
$\mathrm{N}=185$
\end{tabular} & $\begin{array}{l}\mathrm{CD} \\
\mathrm{n}=126\end{array}$ & $\begin{array}{l}\mathrm{UC} \\
\mathrm{n}=59\end{array}$ \\
\hline Age (years) & $37.3(11.8)$ & $36.9(11)$ & $38.1(13.4)$ \\
\hline Male gender, n (\%) & $106(57.3)$ & $75(59.5)$ & $31(52.5)$ \\
\hline Disease duration (years) & $8(25-14)$ & $9(4-15)$ & $6(3-11)$ \\
\hline Body mass index $\left(\mathrm{kg} / \mathrm{m}^{2}\right)$ & $24.3(4.8)$ & $24.2(4.8)$ & $24.4(4.9)$ \\
\hline Smoking, n (\%) & $34(18.4)$ & $28(22.2)$ & $6(10.2)$ \\
\hline $\begin{array}{l}\text { Localization CD, n } \\
\text { L1/L2/L3 }\end{array}$ & & $28 / 18 / 80$ & \\
\hline $\begin{array}{l}\text { Behavior CD, n } \\
\text { B1/B2/B3 }\end{array}$ & & $44 / 48 / 33$ & \\
\hline $\begin{array}{l}\text { Extension UC, n } \\
\text { E1/E2/E3 }\end{array}$ & & & $5 / 12 / 42$ \\
\hline $\begin{array}{l}\text { Surgical resection, n (\%): } \\
\text { Ileum } \\
\text { Colon } \\
\text { Ileum + colon }\end{array}$ & & $\begin{array}{l}12(9.5) \\
23(18.3) \\
27(21.4)\end{array}$ & $4(6.8)$ \\
\hline Perianal disease, $\mathrm{n}(\%)$ & & $19(15.1)$ & \\
\hline $\begin{array}{l}\text { Therapy, } \mathrm{n}(\%) \text { : } \\
\text { Immunomodulators } \\
\text { Anti TNF- } \alpha \\
\text { Anti TNF- } \alpha+\text { immunomodulators } \\
\text { Corticosteroids }\end{array}$ & $\begin{array}{l}24(13) \\
69(37.3) \\
32(17.3) \\
24(13)\end{array}$ & $\begin{array}{l}18(14.3) \\
52(41.3) \\
23(18.3) \\
6(4.8) \\
\end{array}$ & $\begin{array}{l}6(10.2) \\
17(28.8) \\
9(15.3) \\
18(30.5)\end{array}$ \\
\hline Biologic therapy (total), n (\%) & $115(62.2)$ & $85(67.5)$ & $30(50.8)$ \\
\hline Vitamin D supplementation, $\mathrm{n}(\%)$ & $33(17.8)$ & $15(11.9)$ & $18(30.5)$ \\
\hline Enteral nutrition, n (\%) & $21(11.4)$ & $14(11.1)$ & $7(11.9)$ \\
\hline Harvey-Bradshaw index & & $1(0-3)$ & \\
\hline Partial Mayo Score & & & $2(0-4)$ \\
\hline Active disease, $\mathrm{n}(\%)$ & $54(29.2)$ & $23(18.3)$ & $31(52.5)$ \\
\hline Vitamin D level (nmol/L) & $47.3(20.6)$ & $45.9(22.3)$ & $50.3(16.2)$ \\
\hline
\end{tabular}

Categorical variables are shown as absolute number (percentage) and continuous variables as mean (standard deviation) or median (interquartile range); $\mathrm{CD}=$ Crohn's disease; $\mathrm{UC}=$ ulcerative colitis; $\mathrm{TNF}-\alpha=$ tumor necrosis factor alpha

the study. Vitamin D deficiency and insufficiency were defined as levels of vitamin $\mathrm{D}$ lower than $50 \mathrm{nmol} / \mathrm{L}$ and $50-75 \mathrm{nmol} / \mathrm{L}$, respectively. Vitamin D levels higher than or equal to $75 \mathrm{nmol} / \mathrm{L}$ were defined as 'normal' or sufficiency ${ }^{20-22}$. Patients treated with supplementation therapy were defined as taking $800-2000$ IU vitamin $\mathrm{D}$ daily. Patients with vitamin $\mathrm{D}$ deficiency or insufficiency and without vitamin D supplementation were considered untreated. Patients receiving vitamin D supplementation that were still vitamin D deficient or insufficient were considered undertreated.

\section{Statistical analysis}

Percentage was used to report categorical variables, and mean with standard deviation or median with interquartile range $\left(25^{\text {th }}\right.$ and $75^{\text {th }}$ percentiles) to report continuous variables. Distribution relationship between categorical variables was tested using $\chi^{2}$-test or Fisher exact test. Differences between two continuous variables were analyzed using two-way $\mathrm{T}$-test for parametric or Mann-Whitney U-test for non-parametric analysis. To analyze more than two continuous variables, analysis of variance (ANOVA) with Tukey post- 
Table 2. Comparison of demographic and clinical characteristics according to categories of vitamin D levels

\begin{tabular}{|c|c|c|c|c|}
\hline Variable & $\begin{array}{l}\text { Vitamin D } \\
\text { sufficiency } \\
\mathrm{n}=17\end{array}$ & $\begin{array}{l}\text { Vitamin D } \\
\text { insufficiency } \\
\mathrm{n}=60\end{array}$ & $\begin{array}{l}\text { Vitamin D } \\
\text { deficiency } \\
\mathrm{n}=108\end{array}$ & $\mathrm{p}$ value \\
\hline Age (years) & $37.3(11.8)$ & $41.2(12.8)^{* * *}$ & $34.9(10.5)$ & $0.003^{*}$ \\
\hline Male gender, n (\%) & $11(64.7)$ & $39(65)$ & $56(51.9)$ & 0.21 \\
\hline $\begin{array}{l}\text { Phenotype, n (\%): } \\
\text { CD } \\
\text { UC }\end{array}$ & $\begin{array}{l}13(76.5) \\
4(23.5)\end{array}$ & $\begin{array}{l}35(58.3) \\
25(41.7)\end{array}$ & $\begin{array}{l}78(72.2) \\
30(27.8)\end{array}$ & 0.13 \\
\hline Disease duration (years) & $6(1.5-10)$ & $8(3-15)$ & $8(4-13.75)$ & 0.28 \\
\hline Body mass index $\left(\mathrm{kg} / \mathrm{m}^{2}\right)$ & $23.3(2.7)$ & $26.6(4.6)^{* * *}$ & $23.1(4.7)$ & $<0.001^{*}$ \\
\hline Smoking, n (\%) & $2(11.8)$ & $7(11.7)$ & $25(23.1)$ & - \\
\hline $\begin{array}{l}\text { Localization CD, n } \\
\text { L1/L2/L3 }\end{array}$ & $2 / 2 / 9$ & $11 / 7 / 17$ & $15 / 9 / 54$ & 0.30 \\
\hline $\begin{array}{l}\text { Behavior CD, n } \\
\text { B1/B2/B3 }\end{array}$ & $6 / 5 / 2$ & $17 / 9 / 8$ & $21 / 34 / 23$ & 0.14 \\
\hline $\begin{array}{l}\text { Extension UC, n } \\
\text { E1/E2/E3 }\end{array}$ & $0 / 1 / 3$ & $4 / 3 / 18$ & $1 / 8 / 21$ & 0.35 \\
\hline $\begin{array}{l}\text { Surgical resection: } \\
\text { Ileum } \\
\text { Colon } \\
\text { Ileum + colon }\end{array}$ & $\begin{array}{l}1(5.9) \\
2(11.8) \\
2(11.8)\end{array}$ & $\begin{array}{l}3(5) \\
7(11.7) \\
6(10)\end{array}$ & $\begin{array}{l}8(7.4) \\
18(16.7) \\
19(17.6)\end{array}$ & 0.90 \\
\hline Perianal disease, $\mathrm{n}$ & 0 & $6(17.1)$ & $13(16.7)$ & - \\
\hline $\begin{array}{l}\text { Therapy, } \mathrm{n}(\%) \\
\text { Immunomodulators } \\
\text { Anti TNF- } \alpha \\
\text { Anti TNF- } \alpha+\text { immunomodulators } \\
\text { Corticosteroids }\end{array}$ & $\begin{array}{l}3(17.6) \\
7(41.2) \\
0 \\
1(5.9)\end{array}$ & $\begin{array}{l}5(8.3) \\
23(38.33) \\
17(28.33) \\
10(16.7)\end{array}$ & $\begin{array}{l}16(15) \\
39(36.1) \\
15(13.9) \\
13(12)\end{array}$ & 0.71 \\
\hline Biologic therapy (total), n (\%) & $10(58.8)$ & $41(68.3)$ & $64(59.3)$ & 0.49 \\
\hline Vitamin D supplementation, $\mathrm{n}(\%)$ & $6(35.3)$ & $11(18.3)$ & $16(14.8)$ & 0.12 \\
\hline Enteral nutrition, n (\%) & $6(35.3)$ & $4(6.7)$ & $11(10.2)$ & 0.004 \\
\hline Harvey-Bradshaw index & $1(0-2)$ & $1(0-4)$ & $2(0-3.25)$ & 0.22 \\
\hline Partial Mayo Score & $2.5(0-5.75)$ & $2(0-4)$ & $2(0-3.25)$ & 0.99 \\
\hline Active disease, $\mathrm{n}(\%)$ & $2(11.8)$ & $20(33.3)$ & $32(29.6)$ & 0.26 \\
\hline
\end{tabular}

Categorical variables are shown as absolute number (percentage) and continuous variables as mean (standard deviation) or median (interquartile range); ${ }^{*} \mathrm{p}<0.05,{ }^{* *}$ highest value in post-hoc test; TNF- $\alpha=$ tumor necrosis factor alpha

hoc analysis for parametric or Kruskal-Wallis with Mann-Whitney post hoc test for non-parametric analysis was used. Statistical significance was set at 0.05 using IBM SPSS version 23.

\section{Results}

\section{Characteristics of the study population}

Our study included 185 IBD patients, i.e. $68.1 \%$ $(\mathrm{n}=126) \mathrm{CD}$ and $31.9 \%(\mathrm{n}=59)$ UC. Demographic characteristics are shown in Table 1 . The mean age of the total study population was $37.3 \pm 11.8$ years and $57.3 \%(\mathrm{n}=106)$ were male. The mean BMI of the study population was $24.3 \pm 4.8 \mathrm{~kg} / \mathrm{m}^{2}$ (Table 1 ).

\section{Demographic and clinical factors according to categories of vitamin D levels}

Overall, 58.4\% ( $n=108)$ of patients in our study were vitamin $\mathrm{D}$ deficient, and $32.4 \%(\mathrm{n}=60)$ were vita- 
min D insufficient. Patients with vitamin D insufficiency were oldest and had highest BMI $(41.2 \pm 12.8$ years and BMI $26.6 \pm 4.6 \mathrm{~kg} / \mathrm{m})^{2}$ (Table 2)

\section{High prevalence of untreated and undertreated IBD patients}

The rate of untreated patients was $82.2 \%(n=152)$, whereas the rate of undertreated patients was $14.6 \%$ $(\mathrm{n}=27)$. In the groups of patients with vitamin $\mathrm{D}$ insufficiency and deficiency, there was a large proportion of

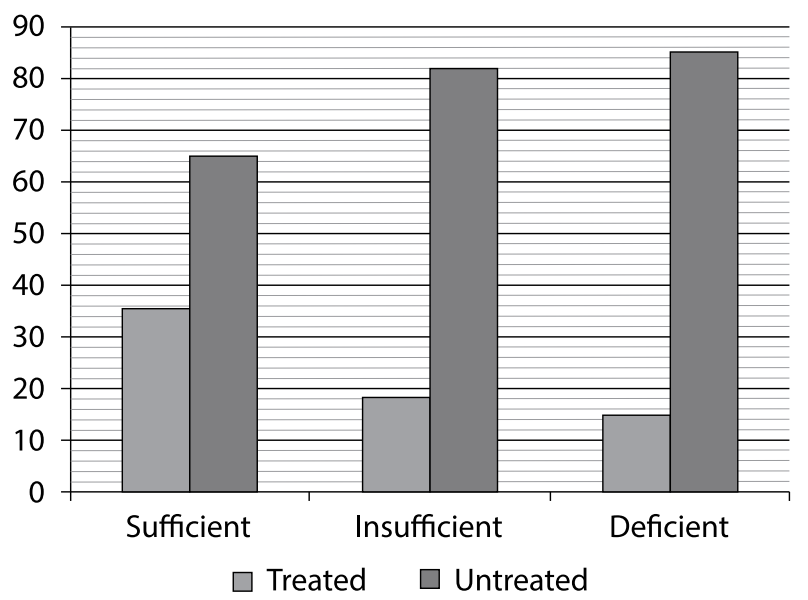

Fig. 1. Proportion of treated and untreated patients in different subgroups of serum vitamin $D$ levels; $X$ axis = vitamin $D$ categories; $Y$ axis = percentage of patients. untreated patients $(81.7 \%(\mathrm{n}=49)$ and $85.2 \%(\mathrm{n}=92)$, respectively), and a relatively large proportion of undertreated patients $(14.8 \%(\mathrm{n}=16)$ in deficient and $18.3 \%(\mathrm{n}=11)$ in insufficient group) (Fig. 1).

\section{Vitamin D supplementation increases 25-OH vitamin D levels}

Vitamin D supplementation was recorded in $14.8 \%$ $(n=16)$ of IBD patients with vitamin D deficiency, $18.3 \%(n=11)$ of those with vitamin D insufficiency and $35.3 \%(n=6)$ of patients with sufficient values. When comparing vitamin D levels in the CD and UC patients with and without supplementation, the difference between vitamin D levels was significant $(\mathrm{p}<0.013$ and $\mathrm{p}<0.05)$ (Figs. 2 and 3).

\section{Vitamin $D$ values do not depend on disease activity}

Patients with CD and UC were analyzed separately. The average HBI and PMS scores in the study population of CD and UC patients were $1(0-3)$ and 2 (0-4), respectively. When comparing vitamin D levels in serum between $\mathrm{CD}$ and UC patients according to disease activity, there was no significant difference ( $\mathrm{p}=0.095$ and $\mathrm{p}=0.82$, respectively) (Fig. 2).

\section{Disease specific medication and vitamin D levels}

Therapy with TNF- $\alpha$ inhibitors was associated with higher serum vitamin $\mathrm{D}$ levels in $\mathrm{CD}(39.3 \pm 28$

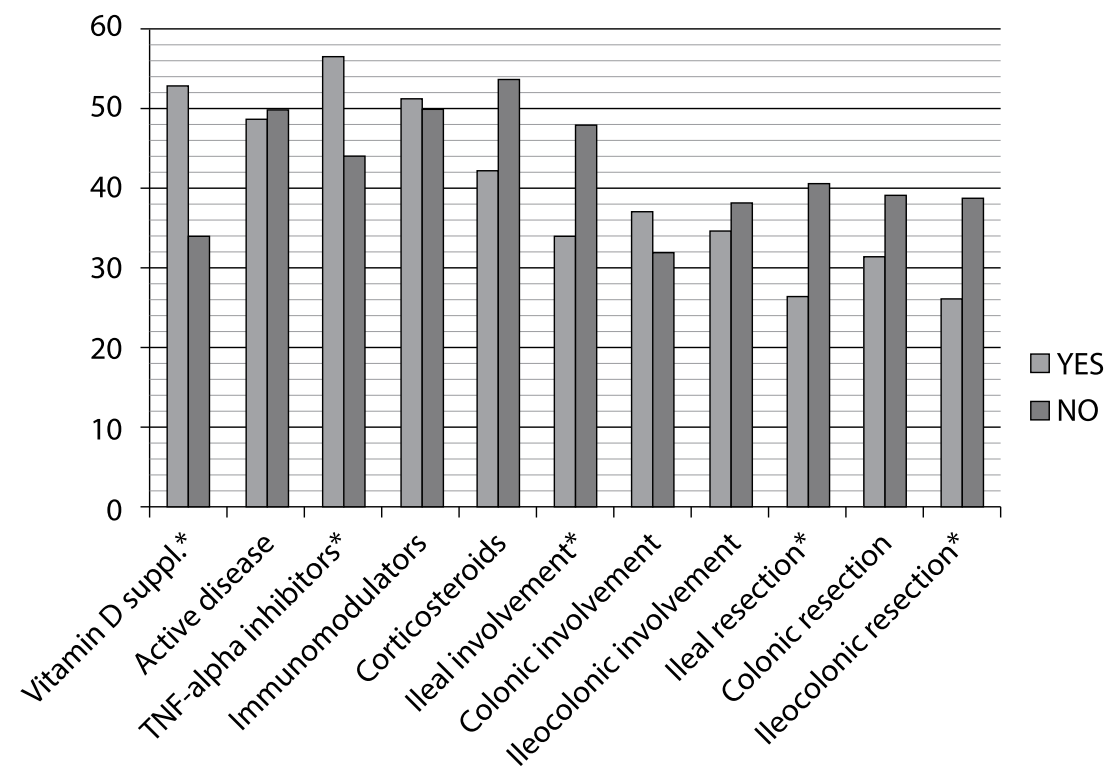

Fig. 2. Vitamin D levels according to different factors in patients with Crohn's disease; Y axis = serum vitamin D levels; ${ }^{*} p<0.05$. 


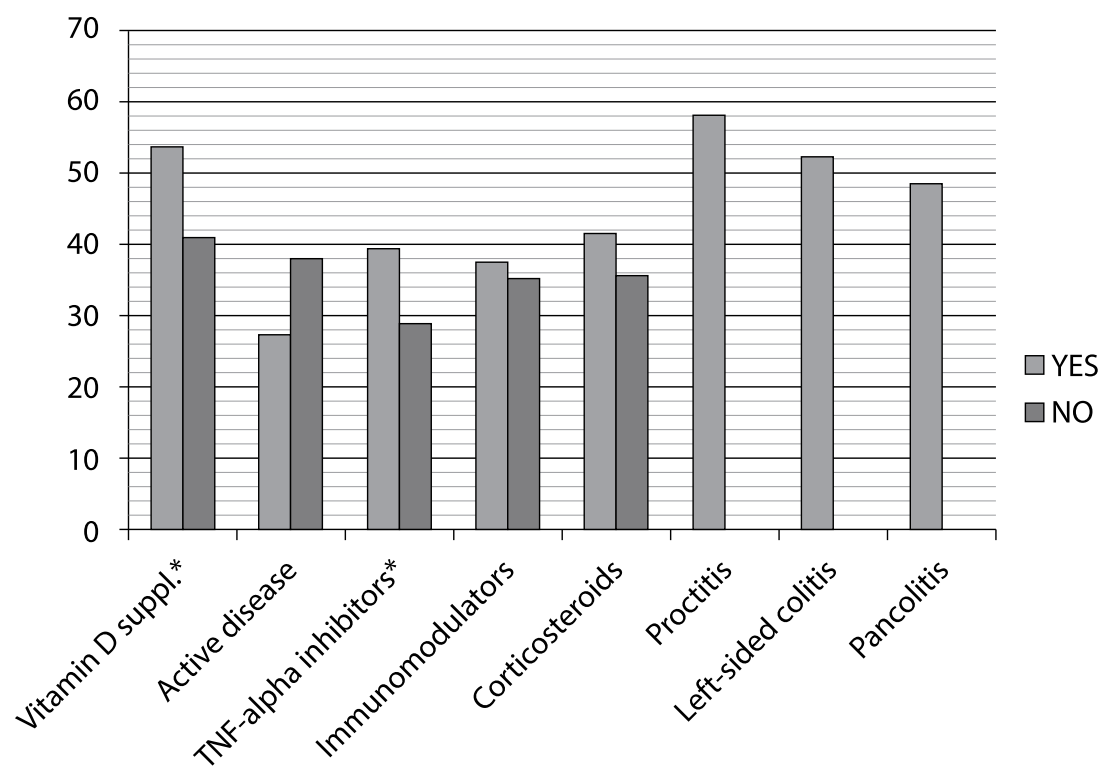

Fig. 3. Vitamin D levels according to different factors in ulcerative colitis;

$Y$ axis $=$ serum vitamin D levels; ${ }^{*} p<0.05$.

vs. $28.9 \pm 23 \mathrm{mmol} / \mathrm{L}, \mathrm{p}=0.049)$ and $\mathrm{UC}(56.3 \pm 20.3$ vs. $43.89 \pm 20.7 \mathrm{mmol} / \mathrm{L}, \mathrm{p}=0.025)$ patients (Figs. 2 and 3 ). In contrast, therapy with immunomodulators and corticosteroids did not influence vitamin $\mathrm{D}$ levels in $\mathrm{CD}$ patients ( $p=0.67$ and $p=0.6$, respectively) (Fig. 2). Similarly, in UC there was no significant difference in vitamin $\mathrm{D}$ levels regarding therapy with immunomodulators $(\mathrm{p}=0.88)$ and corticosteroids either. However, corticosteroid therapy in UC had a trend towards lower vitamin $\mathrm{D}$ levels $(42.2 \pm 19.6$ vs. $53.7 \pm 21.2$ $\mathrm{mmol} / \mathrm{L}, \mathrm{p}=0.058$ (Fig. 3).

\section{Disease localization and extension}

In the majority of $\mathrm{CD}$ patients included in the study, the disease involved both small and large bowel (63.5\%, n=80). In CD patients with involvement of the ileum, vitamin $\mathrm{D}$ levels were significantly lower (33.8 \pm 17 vs. $48 \pm 26 \mathrm{mmol} / \mathrm{L}, \mathrm{p}=0.041$ ) (Fig. 2). Involvement of other parts of the intestine did not significantly affect serum vitamin $\mathrm{D}$ levels. The extension of UC (proctitis, left side, pancolitis) showed no significant difference in serum vitamin $\mathrm{D}$ levels $(\mathrm{p}=0.60)$ (Fig. 3).

\section{Vitamin D values after surgical resections}

We found significant differences in vitamin $\mathrm{D}$ levels between patients having undergone ileal and ilecolonic resection $(26.3 \pm 20$ vs. $40.4 \pm 28 \mathrm{mmol} / \mathrm{L}, \mathrm{p}=0.008$ and $26.1 \pm 11$ vs. $38.7 \pm 18, \mathrm{p}=0.034$, respectively) (Fig. 2).

\section{Discussion}

Recent studies have demonstrated that decreased levels of vitamin $\mathrm{D}$ in serum are a common finding among patients with $\mathrm{CD}$ and $\mathrm{UC}^{1}$. However, there are not enough data analyzing the proportion of untreated and undertreated IBD patients. More than half of the patients (58.4\%) in our study population had vitamin D deficiency, and one-third of patients (32.4\%) had vitamin $\mathrm{D}$ insufficiency. This is in line with other similar studies, which report high proportion of patients who were vitamin $\mathrm{D}$ deficient or insufficient ${ }^{23-26}$. In addition, the average BMI of our cohort was in the normal range, so the patients were not malnourished, which could also be a reason for low vitamin D levels. In a retrospective study by Ulitsky et al. on 504 IBD patients, of which $80 \%$ had been diagnosed with CD, $49.8 \%$ were vitamin $\mathrm{D}$ deficient ${ }^{23}$. Analysis of vitamin $\mathrm{D}$ deficiency in an epidemiological collaboration amongst centers across Europe (Epi-IBD study) including a cohort of 238 patients revealed a prevalence of vitamin D deficiency of $65.4 \%$ in CD and $53.7 \%$ in $\mathrm{UC}$, and vitamin D insufficiency of $17.3 \%$ in $\mathrm{CD}$ and $22.3 \%$ in $\mathrm{UC}^{25}$. Zullow et al. found the prevalence of 
vitamin D deficiency of $38.8 \%$ and vitamin D insufficiency of $28.6 \%{ }^{24}$. Finally, Zator et al. report on $67 \%$ of patients with vitamin $\mathrm{D}$ levels lower than $30 \mathrm{ng} / \mathrm{mL}$ $(75 \mathrm{nmol} / \mathrm{L})^{26}$.

Along with the fact that vitamin $\mathrm{D}$ deficiency is common among IBD patients, the most significant finding in our study was the high proportion of untreated and undertreated patients. There were $81.7 \%$ of untreated patients in vitamin D insufficiency group and $85.2 \%$ in vitamin $\mathrm{D}$ deficiency group. In addition, there were $14.8 \%$ of undertreated patients in vitamin $\mathrm{D}$ deficiency group and $18.3 \%$ of undertreated patients in vitamin $\mathrm{D}$ insufficiency group. These patients were vitamin $\mathrm{D}$ treated but did not achieve sufficient vitamin D levels. This clearly points to the importance of regular vitamin $\mathrm{D}$ level monitoring in patients on supplementation therapy, and even to the need of substitution with higher vitamin $\mathrm{D}$ dosages in a minor proportion of patients. The ECCO and ESGAR guidelines suggest that initial laboratory investigations in IBD patients should include vitamin $\mathrm{D}$, alongside with other routine parameters. In addition, serum vitamin D levels should be measured in symptomatic IBD patients before and after treatment ${ }^{27,28}$. The ESPEN guidelines for clinical nutrition in IBD recommend monitoring of serum vitamin $\mathrm{D}$ and serum calcium in active and steroid-treated patients. If required, supplementation should be given to help in osteopenia or osteoporosis prevention ${ }^{28,29}$. It is suggested that IBD patients should be regularly screened and appropriately corrected not just for vitamin $\mathrm{D}$ deficiency but also for other micronutrient deficiencies ${ }^{27}$. These findings suggest that more emphasis should be placed on detection and adequate treatment of low vitamin D levels.

Our study did not show any association of disease activity with serum vitamin $\mathrm{D}$ levels either in $\mathrm{CD}$ or UC patients. Several studies have reported association between inflammatory activity and vitamin $\mathrm{D}^{23,30-32}$. Meckel et al. showed association of vitamin D deficiency with mucosal inflammation and disease activity in UC patients ${ }^{30}$. In addition, clinical and biochemical disease activity has also been reported as a factor associated with vitamin D deficiency ${ }^{25,31}$. However, in a retrospective study in a single northern German IBD cohort, patients were stratified according to clinical disease activity into highly active (HBI $>9$ or Simple Clinical Colitis Activity Index $(\mathrm{SCCAI})>6$ ) and those in remission (HBI 0-3 or SCCAI 0-2). Significantly lower vitamin D levels were found in UC group with highly active disease, which was not the case for CD'. Furthermore, in our study, patients with involvement of ileum had lower vitamin D levels, which was also the case in patients with ileal and ileocolonic resection. Similar findings were observed in the study by Shäffler et al., where they found a correlation between CD located in small bowel and lower vitamin $\mathrm{D}$ levels, and resection of small bowel and lower vitamin D levels?. Disease activity, localization and surgical resections can cause vitamin $\mathrm{D}$ malabsorption through several different mechanisms. Factors that can lead to decreased absorptive surface are the site of inflammation, affection of small bowel (as in ileal and ileocolonic forms of $\mathrm{CD}$ ), or surgical resections. Active disease can additionally lead to decreased food intake due to anorexia, restricted diets, abdominal pain, nausea, vomiting, etc. ${ }^{33}$. In conclusion, according to current findings, it seems that the disease activity has an effect on vitamin D levels although such analysis in our cohort of patients did not show any significance. Clinical disease activity has its known shortcomings, since there is poor correlation between clinical and endoscopic disease activity. Therefore, endoscopy as the gold standard would be better approach for assessment of disease activity, also taking into account the effect of continuous inflammatory activity, which was not assessed in the above-mentioned studies.

In our study, vitamin $\mathrm{D}$ supplementation was recorded in $17.8 \%$ of IBD patients, $35.3 \%$ of patients with vitamin D sufficiency and $14.8 \%$ of IBD patients with vitamin $\mathrm{D}$ deficiency. As expected, the difference between vitamin $\mathrm{D}$ levels was higher in $\mathrm{CD}$ and $\mathrm{UC}$ patients who were taking vitamin $\mathrm{D}$ supplementation therapy. Also, patients with vitamin D sufficiency had the highest percentage of enteral nutrition supplementation. The Epi-IBD study indicated improvement of vitamin $\mathrm{D}$ levels owing to successful disease control rather than supplementation therapy ${ }^{25}$. If there is inflammation at the site of vitamin $\mathrm{D}$ absorption, control of inflammation could improve vitamin $\mathrm{D}$ absorption. However, vitamin D substitution therapy can be beneficial even in active disease. Even though there is active inflammation, certain part of the small bowel with functional absorptive surface can be intact since the inflammation in $\mathrm{CD}$ is not continuous, and inflammation in UC does not affect small bowel. Further 
studies are needed to address vitamin D supplementation therapy in patients with active or inactive disease.

Our results showed an association between the administration of TNF- $\alpha$ inhibitors with higher vitamin $\mathrm{D}$ levels in IBD patients, which is in line with the study by Schäffler et al. ${ }^{9}$. This study pointed out that patients treated with TNF- $\alpha$ inhibitors could have better disease control ${ }^{9}$. On the other hand, biologic treatment could be a surrogate marker of a more complicated disease or disease that is uncontrollable, has longer disease duration, more bowel resections, etc. Interesting interaction of vitamin D levels and TNF- $\alpha$ inhibitors has been shown in several studies. Zator et al. conclude that patients with vitamin $\mathrm{D}$ insufficiency are prone to earlier discontinuation of antiTNF- $\alpha$ therapy as compared to patients with sufficient vitamin $\mathrm{D}$ levels in serum before starting biologic therapy ${ }^{26}$. In addition, there is evidence that vitamin D levels might be associated with the initial response to TNF- $\alpha$ inhibitors. Winter et al. showed that patients with low vitamin $\mathrm{D}$ levels before starting TNF- $\alpha$ treatment had lower odds for remission after 3 months ${ }^{32}$.

There were several limitations to our study. The study was conducted at a single center with a relatively small patient sample. Since it was a cross-sectional design, our data cannot be used to analyze behavior over a period of disease duration and do not help determine the cause and effect of vitamin D deficiency in IBD. Also, we used clinical indices of disease activity, which correlate poorly with endoscopic disease activity indices.

In conclusion, not only is vitamin $\mathrm{D}$ deficiency common in IBD patients but the proportion of untreated and undertreated patients is also considerably high. This problem has not been emphasized in similar studies so far. Our suggestion is to monitor vitamin D levels in IBD patients regularly, regardless of receiving vitamin $\mathrm{D}$ supplementation, and to adjust vitamin $\mathrm{D}$ supplementation therapy. Additional studies are needed to explore the possible impact of vitamin D in IBD pathogenesis given the consistent reports of low levels in this patient population.

\section{References}

1. Park SJ, Kim WH, Cheon JH. Clinical characteristics and treatment of inflammatory bowel disease: a comparison of Eastern and Western perspectives. World J Gastroenterol. 2014;20:11525-37. doi: 10.3748/wjg.v20.i33.11525
2. Thia KT, Loftus E V., Sandborn WJ, Yang SK. An update on the epidemiology of inflammatory bowel disease in Asia. Am J Gastroenterol. 2008;103:3167-82. doi: 10.1111/j.1572-0241. 2008.02158.x

3. Molodecky NA, Soon IS, Rabi DM, Ghali WA, Ferris M, Chernoff $\mathrm{G}$, et al. Increasing incidence and prevalence of the inflammatory bowel diseases with time, based on systematic review. Gastroenterology. 2012;142:46-54.e42. doi: 10.1053/j. gastro.2011.10.001

4. Piovani D, Danese S, Peyrin-Biroulet L, Nikolopoulos GK, Lytras T, Bonovas S. Environmental risk factors for inflammatory bowel diseases: an umbrella review of meta-analyses. Gastroenterology. 2019;157:647-59.e4. doi: 10.1053/j.gastro.2019. 04.016

5. Ananthakrishnan AN, Khalili H, Higuchi LM, Bao Y, Korzenik JR, Giovannucci EL, et al. Higher predicted vitamin D status is associated with reduced risk of Crohn's disease. Gastroenterology. 2012;142:482-9. doi: 10.1053/j.gastro.2011.11.040

6. Hewison M. Vitamin D and immune function: an overview. Proc Nutr Soc. 2012;71:50-61. doi: 10.1017/S0029665111 001650

7. Chambers ES, Hawrylowicz CM. The impact of vitamin D on regulatory T cells. Curr Allergy Asthma Rep. 2011;11:29-36. doi: $10.1007 / \mathrm{s} 11882-010-0161-8$

8. Zhao H, Zhang H, Wu H, Li H, Liu L, Guo J, et al. Protective role of $1,25(\mathrm{OH}) 2$ vitamin D 3 in the mucosal injury and epithelial barrier disruption in DSS-induced acute colitis in mice. BMC Gastroenterol. 2012;12:57. doi: 10.1186/1471-230X$12-57$

9. Schäffler H, Schmidt M, Huth A, Reiner J, Glass Ä, Lamprecht $\mathrm{G}$. Clinical factors are associated with vitamin D levels in IBD patients: a retrospective analysis. J Dig Dis. 2018;19: 24-32. doi: 10.1111/1751-2980.12565

10. Compston JE, Creamer B. Plasma levels and intestinal absorption of 25 hydroxyvitamin $\mathrm{D}$ in patients with small bowel resection. Gut. 1977;18:171-5. doi: 10.1136/gut.18.3.171

11. Shivananda S, Lennard-Jones J, Logan R, Fear N, Price A, Carpenter L, et al. Incidence of inflammatory bowel disease across Europe: is there a difference between north and south? Results of the European Collaborative Study on Inflammatory Bowel Disease (EC-IBD). Gut. 1996;39:690-7. doi: 10.1136/ gut.39.5.690

12. Nerich V, Monnet E, Etienne A, Louafi S, Ramée C, Rican S, et al. Geographical variations of inflammatory bowel disease in France: a study based on national health insurance data. Inflamm Bowel Dis. 2006;12:218-26. doi: 10.1097/01.MIB. $0000206540.38834 .8 \mathrm{c}$

13. Jussila A, Virta LJ, Salomaa V, Mäki J, Jula A, Färkkilä MA. High and increasing prevalence of inflammatory bowel disease in Finland with a clear north-south difference. J Crohns Colitis. 2013;7:e256-62. doi: 10.1016/j.crohns.2012.10.007

14. Gubatan J, Mitsuhashi S, Zenlea T, Rosenberg L, Robson S, Moss AC. Low serum vitamin D during remission increases 
risk of clinical relapse in patients with ulcerative colitis. Clin Gastroenterol Hepatol. 2017;15:240-6.e1. doi: 10.1016/j.cgh. 2016.05.035

15. Kabbani TA, Koutroubakis IE, Schoen RE, Ramos-Rivers C, Shah N, Swoger J, et al. Association of vitamin D level with clinical status in inflammatory bowel disease: a 5-year longitudinal study. Am J Gastroenterol.2016;111:712-9. doi: 10.1038/ ajg.2016.53

16. Gubatan J, Moss AC. Vitamin D in inflammatory bowel disease: more than just a supplement. Curr Opin Gastroenterol. 2018;34:217-25. doi: 10.1097/MOG.0000000000000449

17. Brooke B. Index of Crohn's disease activity. Lancet. 1980; 315:711.

18. Lewis JD, Chuai S, Nessel L, Lichtenstein GR, Aberra FN, Ellenberg JH. Use of the noninvasive components of the Mayo score to assess clinical response in ulcerative colitis. Inflamm Bowel Dis. 2008;14:1660-6. doi: 10.1002/ibd.20520

19. Satsangi J, Silverberg MS, Vermeire S, Colombel JF. The Montreal classification of inflammatory bowel disease: controversies, consensus, and implications. Gut. 2006;55:749-53. doi: 10.1136/gut.2005.082909

20. Holick MF. Optimal vitamin D status for the prevention and treatment of osteoporosis. Drugs Aging. 2007;24:1017-29. doi: 10.2165/00002512-200724120-00005

21. Holick MF. Sunlight and vitamin D for bone health and prevention of autoimmune diseases, cancers, and cardiovascular disease. Am J Clin Nutr. 2004;80:1678-88. doi: 10.1093/ ajcn/80.6.1678S

22. Adams JS, Hewison M. Update in vitamin D. J Clin Endocrinol Metab. 2010;95:471-8. doi: 10.1210/jc.2009-1773

23. Ulitsky A, Ananthakrishnan AN, Naik A, Skaros S, Zadvornova Y, Binion DG, et al. Vitamin D deficiency in patients with inflammatory bowel disease: association with disease activity and quality of life. J Parenter Enter Nutr. 2011;35:308-16. doi: $10.1177 / 0148607110381267$

24. Zullow S, Jambaulikar G, Rustgi A, Quezada S, Cross RK. Risk factors for vitamin $\mathrm{D}$ deficiency and impact of repletion in a tertiary care inflammatory bowel disease population. Dig Dis Sci. 2017;62:2072-8. doi: 10.1007/s10620-017-4614-y

25. Zammit SC, Ellul P, Girardin G, Valpiani D, Nielsen KR, O1sen J, et al. Vitamin D deficiency in a European inflammatory bowel disease inception cohort: an Epi-IBD study. Eur J
Gastroenterol Hepatol. 2018;30:1297-303. 10.1097/MEG.00 00000000001238

26. Zator ZA, Cantu SM, Konijeti GG, Nguyen DD, Sauk J, Yajnik V, et al. Pretreatment 25-hydroxyvitamin D levels and durability of anti-tumor necrosis factor- $\alpha$ therapy in inflammatory bowel diseases. J Parenter Enter Nutr. 2014;38:385-91. doi: $10.1177 / 0148607113504002$

27. Maaser C, Sturm A, Vavricka SR, Kucharzik T, Fiorino G, Annese $V$, et al. ECCO-ESGAR Guideline for Diagnostic Assessment in IBD Part 1: Initial diagnosis, monitoring of known IBD, detection of complications. J Crohns Colitis. 2019;13: 144-64. doi: 10.1093/ecco-jcc/jjy113

28. Magro F, Gionchetti P, Eliakim R, Ardizzone S, Armuzzi A, Barreiro-de Acosta M, et al. Third European evidence-based consensus on diagnosis and management of ulcerative colitis. Part 1: Definitions, diagnosis, extra-intestinal manifestations, pregnancy, cancer surveillance, surgery, and ileo-anal pouch disorders. J Crohns Colitis. 2017;11:649-70. doi: 10.1093/ecco-jcc/jjx008

29. Forbes A, Escher J, Hébuterne X, Kłęk S, Krznaric Z, Schneider $\mathrm{S}$, et al. ESPEN guideline: Clinical nutrition in inflammatory bowel disease. Clin Nutr. 2017;36:321-47. doi: 10.1016/j. clnu.2016.12.027

30. Meckel K, Li YC, Lim J, Kocherginsky M, Weber C, Almoghrabi A, et al. Serum 25-hydroxyvitamin D concentration is inversely associated with mucosal inflammation in patients with ulcerative colitis. Am J Clin Nutr. 2016;104:113-20. doi: 10.3945/ajcn.115.123786

31. Scolaro BL, Barretta C, Matos CH, Fernando E, Bampi I, Almeida $T$ De, et al. Deficiency of vitamin $\mathrm{D}$ and its relation with clinical and laboratory activity of inflammatory bowel diseases. J Coloproctol (Rio J). 2018;38:99-104. doi: 10.1016/j.jcol. 2017.11.005

32. Winter RW, Collins E, Cao B, Carrellas M, Crowell AM, Korzenik JR. Higher 25-hydroxyvitamin D levels are associated with greater odds of remission with anti-tumour necrosis factor- $\alpha$ medications among patients with inflammatory bowel diseases. Aliment Pharmacol Ther. 2017;45:653-9. doi: 10.1111 /apt.13936

33. Massironi S, Rossi RE, Cavalcoli FA, Della Valle S, Fraquelli M, Conte D. Nutritional deficiencies in inflammatory bowel disease: therapeutic approaches. Clin Nutr. 2013;32:904-10. doi: 10.1016/j.clnu.2013.03.020 


\title{
Sažetak \\ VISOKA UČESTALOST NELIJEČENE I NEDOVOLJNO LIJEČENE DEFICIJENCIJE I INSUFICIJENCIJE VITAMINA D U BOLESNIKA S UPALNIM BOLESTIMA CRIJEVA
}

\author{
V. Domislović, D. Vranešić Bender, A. Barišic, M. Brinar, D. Ljubas Kelečic, C. Rotim, M. Novosel, M. Matašin i Ž. Krznaric
}

Bolesnici s upalnim bolestima crijeva (inflammatory bowel disease, IBD) i manjkom vitamina $\mathrm{D}$ su pod povećanim rizikom hospitalizacije, operacije i gubitka odgovora na biološku terapiju, dok visoke serumske razine vitamina $D$ predstavljaju zaštitni čimbenik. Cilj ove studije bio je istražiti učestalost neliječenih i nedovoljno liječenih bolesnika s IBD i manjkom vitamina $\mathrm{D}$ te čimbenike rizika. U ovoj presječnoj studiji mjerene su serumske razine vitamina $\mathrm{D}$ u slučajnom uzorku bolesnika s IBD bijele rase. Deficijencija je definirana kao razine $<50 \mathrm{nmol} / \mathrm{L}$, a insuficijencija kao $50-75 \mathrm{nmol} / \mathrm{L}$. Nadoknada vitamina $\mathrm{D}$ je definirana kao uzimanje 800-2000 IJ vitamina D na dan. Neliječeni bolesnici su oni bez nadoknade, a nedovoljno liječeni oni s deficijencijom ili insuficijencijom usprkos nadoknadi. Uključeno je ukupno 185 bolesnika s IBD, tj. $126(68,1 \%)$ s Crohnovom bolešću i 59 (31,9\%) s ulceroznim kolitisom. Ukupno je 108 (58,4\%) bolesnika imalo deficijenciju, a $60(32,4 \%)$ insuficijenciju. Udio liječenih bolesnika s deficijencijom i insuficijencijom vitamina D iznosio je 14,8\% ( $n=16)$ i 18,3\% ( $n=11)$. Udio neliječenih s deficijencijom iznosio je 81,7\% ( $n=49)$, a s insuficijencijom 85,2\% ( $n=92)$. Terapija inhibitorima faktora tumorske nekroze alfa bila je povezana s višim razinama vitamina $D$. Niže razine vitamina $D$ su zabilježene kod bolesnika s upalom u području ileuma i resekcijom ileuma ili ileokolona. $U$ zaključku, niske serumske razine vitamina $\mathrm{D}$ su česta pojava kod bolesnika s IBD, a dodatno je udio neliječenih i nedovoljno liječenih također visok. Naša preporuka je kontinuirano praćenje razina vitamina $\mathrm{D}$ u serumu svih bolesnika s IBD uključujući i one na nadoknadi vitaminom D.

Ključne riječi: Upalne bolesti crijeva; Vitamin D, nedostatak; Crohnova bolest; Kolitis, ulcerozni 